\title{
SOEP
}

SOEPpapers

SOEPpapers
on Multidisciplinary Panel Data Research
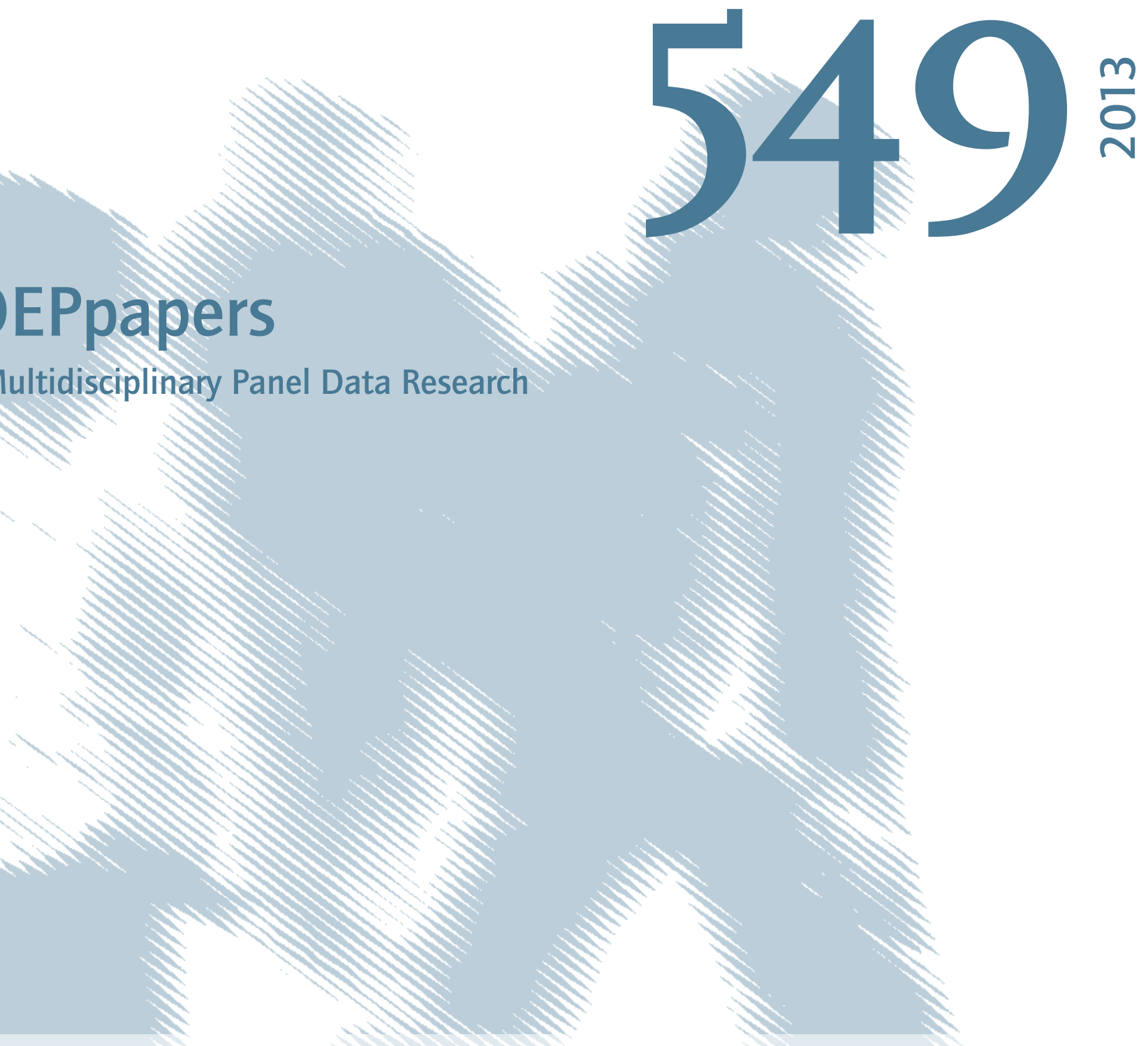

\section{Direct Evidence on Income Comparisons and Subjective Well-Being}




\section{SOEPpapers on Multidisciplinary Panel Data Research}

at DIW Berlin

This series presents research findings based either directly on data from the German SocioEconomic Panel Study (SOEP) or using SOEP data as part of an internationally comparable data set (e.g. CNEF, ECHP, LIS, LWS, CHER/PACO). SOEP is a truly multidisciplinary household panel study covering a wide range of social and behavioral sciences: economics, sociology, psychology, survey methodology, econometrics and applied statistics, educational science, political science, public health, behavioral genetics, demography, geography, and sport science.

The decision to publish a submission in SOEPpapers is made by a board of editors chosen by the DIW Berlin to represent the wide range of disciplines covered by SOEP. There is no external referee process and papers are either accepted or rejected without revision. Papers appear in this series as works in progress and may also appear elsewhere. They often represent preliminary studies and are circulated to encourage discussion. Citation of such a paper should account for its provisional character. A revised version may be requested from the author directly.

Any opinions expressed in this series are those of the author(s) and not those of DIW Berlin. Research disseminated by DIW Berlin may include views on public policy issues, but the institute itself takes no institutional policy positions.

The SOEPpapers are available at

http://www.diw.de/soeppapers

\section{Editors:}

Jürgen Schupp (Sociology, Vice Dean DIW Graduate Center)

Gert G. Wagner (Social Sciences)

Conchita D'Ambrosio (Public Economics)

Denis Gerstorf (Psychology, DIW Research Director)

Elke Holst (Gender Studies, DIW Research Director)

Frauke Kreuter (Survey Methodology, DIW Research Professor)

Martin Kroh (Political Science and Survey Methodology)

Frieder R. Lang (Psychology, DIW Research Professor)

Henning Lohmann (Sociology, DIW Research Professor)

Jörg-Peter Schräpler (Survey Methodology, DIW Research Professor)

Thomas Siedler (Empirical Economics)

C. Katharina Spieß (Empirical Economics and Educational Science)

ISSN: 1864-6689 (online)

German Socio-Economic Panel Study (SOEP)

DIW Berlin

Mohrenstrasse 58

10117 Berlin, Germany

Contact: Uta Rahmann | soeppapers@diw.de 


\title{
Direct Evidence on Income Comparisons and Subjective Well-Being*
}

\author{
Laszlo Goerke \\ IAAEU - University of Trier ${ }^{+}$, IZA, Bonn and CESifo, München \\ + Institute for Labor Law and Industrial Relations in the European Union, Campus II \\ D - 54286 Trier, Germany \\ E-mail: goerke(at)iaaeu.de
}

$\&$

Markus Pannenberg

University of Applied Sciences Bielefeld ${ }^{++}$, DIW, Berlin and IZA, Bonn

++ Department of Business and Economics, Universitätsstraße 25

D-33615 Bielefeld, Germany

E-mail: markus.pannenberg(at)fh-bielefeld.de

this version: March 18, 2013

\begin{abstract}
Subjective well-being (SWB) is generally argued to rise with relative income. However, direct evidence is scarce on whether and how intensively individuals undertake income comparisons, to whom they relate, and what they perceive their relative income to be. In this paper, novel data with direct information on income comparison intensity and perceived relative income with respect to predetermined reference groups is used to provide evidence on the relationship between income comparisons and SWB. We find negative correlations between comparison intensity and SWB for co-workers, people in the same occupation and friends. For job-related reference groups income comparisons are mostly upwards and perceiving to earn less than the reference group is negatively correlated with SWB.
\end{abstract}

JEL-Classification: D 31, D 62, I 31

Keywords: Income Comparisons, Endogenous Reference Groups, German Socio-Economic Panel (SOEP), Subjective Well-Being

* We are grateful to Adrian Chadi, Guido Heineck, Andreas Knabe, Mario Mechtel and Semih Tümen for helpful comments on a first, shorter version of this paper. 


\section{Introduction}

People compare themselves to others, especially in terms of income. Accordingly, there are numerous studies showing that relative income affects subjective well-being (as documented, for example, in the surveys by Clark et al. 2008 and Dolan et al. 2008). However, virtually all investigations establishing such a link face at least one of the following fundamental problems: researchers do not know, first, what is the importance of income comparisons for individuals, second, how people assess different reference groups and third, what individuals perceive their income to be, relative to that of the relevant reference group. The first problem is typically ignored. Researchers usually solve the second by defining hypothetical reference groups in terms of observable criteria, such as age, education and geographical proximity. While such an approach does not lack plausibility, we generally do not have information whether such hypothetical reference groups are adequate proxies for an individual's true standard of comparison. In order to tackle the third problem, observed or estimated average income of hypothetical reference groups deemed to be relevant by the investigator is frequently used as a proxy for perceived relative income. However, emotional responses to income comparisons, which are related to subjective well-being, are most likely to be affected by what individuals believe members of the reference group to earn, given that the others' true income may not be perfectly observable (e.g. de la Garza et al. 2012).

There are few studies in which some of these problems can either be circumvented or solved. Clark/Senik (2010), for example, utilise a measure of general income comparison intensity from the European Social Survey ("How important is it for you to compare your income with other people's income?"). Furthermore, they have information on the direction of income comparison, i.e. whose income respondents are most likely to compare their own income with. Similarly, Clark et al. (2013) relate an indicator of comparison intensity ("How much are you concerned, anxious or envious about other people's income?") for respondents of an internet survey from Japan to financial satisfaction. In addition, respondents can state the most important reference category (family, neighbour, friend, colleague or others) and are asked to provide information about the perceived income of "people of the same age, sex, and education level". Clark/Senik (2010) and Clark et al. (2013) are, thus, partially able to tackle the first and second problem mentioned in the previous paragraph. However, due to the data at hand they still face the problem that their respondents might choose the preferred reference group endogenously. Moreover, the relative income information is not specific to particular reference groups. Knight et al. (2009) can also avoid the second challenging aspect because 
they utilise information on the main income comparison group of Chinese rural dwellers. Turning to the third problem, the US General Social Survey contains a question on perceived relative family income with respect to "American families in general" (also used, for example, by Layard et al. 2010 and Guven/Sørensen 2012). Hence, there is no direct linkage between relevant reference groups and perceived relative income. de la Garza et al. (2012) can partly cater for this issue since they relate the happiness of Japanese union members working in major publicly-traded companies to the perceived wages of their co-workers. Consequently, in all of these contributions at least one but never all of the three problems listed above have been tackled.

In this paper, we can address all three aspects because in our survey data employees report how important they regard income comparisons with respect to nine predetermined reference groups and what they believe their income is relative to that of these reference groups. This implies, inter alia, that respondents do not have to choose a particular reference group. Consequently, we come much closer than previous contributions to what Clark/ Senik (2010) label an "ideal data set". ${ }^{1}$ In particular, using three pretest modules of the German SocioEconomic Panel (SOEP) for the years 2008-10, we find that subjective well-being is correlated with the perceived income of colleagues, other people in the same occupation and friends, but not with that of other reference groups, such as neighbours or partners. In addition, the intensity of income comparison affects subjective well-being on its own. In consequence, studies ignoring the intensity aspect, defining reference groups along 'objective' criteria observable to the researcher and using true information on income might miss important aspects of the association between subjective well-being and relative income. In sum, we provide new direct evidence on the relationship between happiness and (the importance of) income comparisons.

In the further course of our study, we describe the data and explain our empirical approach in Section 2. In Section 3 we present our main findings, while in Section 4 the results from various robustness checks are reported. We summarise our key insights in Section 5.

\footnotetext{
1 "In an ideal dataset, we would be able to combine information on both own income .. and reference income .. with our measure of comparison intensity ..." (Clark/Senik 2010, p. 579). See also McBride (2001) who discusses extensively desirable features of data for research on life satisfaction. The main element our data is missing, despite its great advantages, is probably that respondents do not participate in pretests repeatedly.
} 


\section{Data, Empirical Specifications and Descriptive Evidence}

Data

Our analysis is based on the pretest modules 2008-2010 of the German Socio-Economic Panel (SOEP), a nationally representative household survey. We are restricted to these years because the survey instruments used to collect information about the intensity of income comparisons and relative incomes were introduced in the 2008 pretest module and improved in the following two years but no longer included in the 2011 edition. By design SOEP pretest modules are self-contained representative random samples of the resident population in Germany. The 2010 SOEP pretest consists of data entries from 1315 respondents. They come from three subsamples, namely two standard random samples and one (sub-) sample of employed respondents from two random SOEP pilot studies. The two SOEP pretest modules in 2008 and 2009 are also standard random samples with about 1000 respondents. Our pooled working sample is restricted to employed respondents aged 17 to 65 years in the respective years. $^{2}$

A key comparative advantage of the SOEP data at hand is that they provide unparalleled direct information on the intensity of income comparisons and perceived relative income of respondents with respect to an exogenously given set of nine reference groups. In 2010, for example, employed respondents were asked: "When you think about your gross labour income compared to that of other individuals: How important is it to you how your gross income compares to that of: (a) your neighbours, (b) your friends, (c) your colleagues at the workplace, (d) other people in your occupation, (e) people of your age, (f) your parents when they were your age, (g) your partner, (h) other women or (i) other men". Respondents were requested to state the intensity of income comparisons on a seven-point scale for every reference group, ranging from "completely unimportant (1)" to "extremely important (7)". A second income comparison question followed directly afterwards and read: "And how high is your gross income in comparison to the following people: ..." Subsequently, the same list of nine potential reference groups as above was provided. Respondents were asked to state their relative income position on a five-point scale, ranging from "much lower (1)" to "much higher (5)". Note that the wording of the two income comparison questions was slightly refined over

\footnotetext{
2 Detailed information on the SOEP pretest modules is provided in the yearly documentations ("Methodenbericht"; http://www.diw.de/en/diw_01.c.389728.en/soep_survey_papers.html). For general information about the SOEP see http://www.diw.de/en/soep and Wagner et al. (2007). Weights provided with the SOEP pretest modules are based on a raking algorithm in order to fit a few external regional and demographic marginal distributions. Hence, we use weights in the descriptive analysis, but not in the regression exercises.
} 
the years. First, in 2008 the questions referred to income instead of gross income. ${ }^{3}$ Second, in 2009, the wording of the two gender-specific reference groups was "women (men) in general" instead of "other women (men)". However, the basic structure of the relevant questions and their position in the questionnaire were unaffected.

Information on subjective well-being (SWB) stems from the standard life satisfaction question "How satisfied are you with your life, all things considered?" with responses given on a 0-10 scale where 0 means "completely dissatisfied" and 10 means "completely satisfied". The SOEP pretest modules furthermore contain only a subset of those questions regularly asked in the main questionnaires, thus restricting the feasible set of covariates.

\section{Empirical Specification}

Our subjective well-being-model is specified as follows:

$$
S W B_{i}=\alpha+i c_{-} \text {int }_{i} * \beta+I\left(p_{-} r e l i n c_{i}\right) * \delta+\ln \left(y_{i}\right) * \tau+x_{i} * \theta+\varepsilon_{i},
$$

where $i c_{-} i n t_{i}$ is the ordinal measure of income comparison intensity with respect to one of the nine reference groups of individual $i, I\left(p_{-} r e l i n c_{i}\right)$ is (a function $I$ of) the corresponding ordinal measure of the perceived relative gross income, $y_{i}$ is net monthly household income, $x_{i}$ is a vector of further covariates, which includes dummy variables for gender, education, firm size, public sector affiliation, the presence of children of less than 16 years of age in the household, marital status, professional status (being an employed white or blue collar worker or being self-employed), and working part-time as well as age (and age squared), and $\varepsilon_{i}$ is an idiosyncratic error term. As an alternative to the plain ordinal measures $i c_{-} i n t_{i}$ and $I\left(p_{-} r e l i n c_{i}\right)$, we also use dummy variable specifications, where $i c_{-} i m p_{i},=1$ indicates that income comparisons are important (values 5 to 7), and less_inc $c_{i}$ and more_inc ${ }_{i}$ are set equal to 1 if respondents report that their own income is lower (values 1 and 2) or higher (values 4 and 5) than the income of the particular reference group. The parameters of equation (1) are estimated using OLS. However, it is well known that OLS-specifications impose constant marginal effects and might lead to predictions of subjective well-being outside the logically possible range of values. As a check of robustness, we therefore estimate a rating scale model by means of Bernoulli Quasi-Maximum-Likelihood with logit link function, recently suggested by Studer/Winkelmann (2012). Their econometric approach overcomes both limitations. Descriptive statistics of all variables used in our analysis are documented in Tables A1a/b in the Appendix.

\footnotetext{
${ }^{3}$ The main results presented below remain unchanged when we exclude data from the pretest 2008 from our empirical analysis.
} 
We started our empirical investigation with various specifications of equation (1) for all nine potential reference groups. The first noteworthy finding is that there are robust significant correlations between the income comparison variables and subjective well-being across all specifications for the following three reference groups only: colleagues at the work place, other people in your occupation and your friends. Hence, for Germany we do not obtain evidence that perceived relative income affects subjective well-being with respect to reference groups like neighbours. This is in contrast to findings from studies in which relative income of neighbours is implicitly identified with respect to hypothetical reference groups in small local areas defined by the researcher (e.g. Luttmer 2005 for the United States and Knies 2012 for Germany). In addition, our findings do not suggest that the comparison with parents affects subjective well-being in Germany (see Senik 2009 for according results).

\section{Descriptive Evidence}

Table 1 presents the distributions for the measure of income comparison intensity as well as for the perceived relative income for those reference groups, for which we find that income comparisons matter. Although a remarkable fraction of employees (30\%-35\%) regard income comparisons with respect to the two job-related reference groups as completely unimportant, we also observe that $30 \%-40 \%$ of them classify these income comparisons as essential (values 5 to 7$).{ }^{4}$ Moreover, roughly two out of three employees perceive that they earn about the same as their job-related reference groups, while $20 \%-25 \%$ report lower perceived incomes. ${ }^{5}$ Income comparisons with friends, however, appear to be less important.

\footnotetext{
${ }^{4}$ Clark/Senik (2010) report a similar distribution of a general measure of income comparison intensity based on data from 18 European countries. This also holds for Mayraz et al. (2010), who use the SOEP pretest module 2008 only, and for the sample of respondents from Japan employed by Clark et al. (2013).

${ }^{5}$ Similar numbers are documented by Mayraz et al. (2010) for the 2008 pretest. Moreover, Guven/Sørensen (2012) report for the US that about half of respondents believe that their income is about average. Comparable numbers can be derived from Knight et al. (2009) for Chinese households. Accordingly, the use of broad comparison intervals with respect to income seems to be a common feature.
} 
Table 1: Income Comparisons and Perceived Relative Income in Germany

\begin{tabular}{|c|c|c|c|c|}
\hline Reference Group & & $\begin{array}{l}\text { Colleagues at } \\
\text { the work place }\end{array}$ & $\begin{array}{l}\text { Other people in } \\
\text { your occupation }\end{array}$ & Your friends \\
\hline \multicolumn{5}{|c|}{ Income Comparison Intensity $\left(i c_{-} i n t_{i}\right)($ in $\%)$} \\
\hline \multirow{6}{*}{ Completely unimportant } & (1) & 34.48 & 29.09 & 51.34 \\
\hline & (2) & 8.97 & 7.18 & 13.73 \\
\hline & (3) & 9.37 & 7.42 & 11.29 \\
\hline & (4) & 17.22 & 16.69 & 13.09 \\
\hline & (5) & 12.82 & 15.45 & 6.72 \\
\hline & (6) & 11.11 & 15.25 & 3.17 \\
\hline Extremely important & (7) & 6.03 & 8.92 & 0.65 \\
\hline $\mathrm{N}$ & & 1,173 & 1,191 & 1,191 \\
\hline \multicolumn{5}{|c|}{ Perceived Relative Income $\left(I\left(p_{-} r e l i n c_{i}\right)\right)($ in $\%)$} \\
\hline Much lower & (1) & 7.77 & 6.32 & 9.04 \\
\hline Somewhat lower & (2) & 12.94 & 18.11 & 21.26 \\
\hline About the same & (3) & 67.39 & 64.67 & 49.45 \\
\hline Somewhat higher & (4) & 9.95 & 9.72 & 18.26 \\
\hline Much higher & (5) & 1.94 & 1.17 & 1.99 \\
\hline $\mathrm{N}$ & & 1,031 & 1,058 & 994 \\
\hline
\end{tabular}

Source: SOEP pretest modules 2008-2010. Weighted statistics.

One might speculate that income comparison intensity and perceived relative income are linked due to various phenomena, e.g. respondents with perceived high relative income state that income comparisons are important and vice versa. However, we do not find any notable correlation patterns between $i c_{-} i n t_{i}$ and $I\left(p_{-}\right.$relinc $\left._{i}\right)$ in our working sample. The estimated pairwise correlation coefficients are 0.07 (colleagues) and 0.01 (other people in your occupation, friends). Finally, note that there is remarkable variation across reference groups at the individual level: Only 39\% of all respondents report the same income comparison intensity across the three reference groups. Moreover, only $41 \%$ of all respondents exhibit the same relative income position across the three reference groups (both results are not documented).

\section{Regression Results}

Table 2 below shows OLS results for the three different reference groups as well as for the reference group among these three which respondents classify as most important in terms of comparison intensity. ${ }^{6}$ We also report the estimated coefficients for the (log of) net monthly household income in Table 2 but omit those for other covariates, which are in line with the

\footnotetext{
${ }^{6}$ In case of respondents reporting identical income comparison intensities across reference groups information for the reference group "other people in your occupation" is used.
} 
evidence conveyed in other studies (e.g. Ferrer-i-Carbonell 2005). Full results for the specification contained in the upper half of Table 2 are presented in the Appendix, Table A2.

Table 2: Subjective Well-Being and Income Comparisons

\begin{tabular}{|c|c|c|c|c|}
\hline $\begin{array}{l}\text { Reference } \\
\text { Group }\end{array}$ & $\begin{array}{l}\text { Colleagues at } \\
\text { the work place }\end{array}$ & $\begin{array}{l}\text { Other people } \\
\text { in your } \\
\text { occupation }\end{array}$ & Your friends & $\begin{array}{l}\text { Most impor- } \\
\text { tant one w.r.t. } \\
\quad \text { ic_int }_{i}\end{array}$ \\
\hline \multicolumn{5}{|c|}{ ic_int $_{i}:$ ordinal $\& I\left(p_{-}\right.$relinc $\left.c_{i}\right):$ ordinal } \\
\hline$i c_{-} i n t_{i}$ & $\begin{array}{l}-0.083 * * \\
(0.028)\end{array}$ & $\begin{array}{l}-0.074^{* *} \\
(0.026)\end{array}$ & $\begin{array}{l}-0.087^{*} \\
(0.034)\end{array}$ & $\begin{array}{l}-0.088^{* *} \\
(0.027)\end{array}$ \\
\hline$I\left(p_{-}\right.$relinc $\left._{i}\right)$ & $\begin{array}{c}0.133+ \\
(0.071)\end{array}$ & $\begin{array}{l}0.229 * * \\
(0.071)\end{array}$ & $\begin{array}{c}0.106+ \\
(0.056)\end{array}$ & $\begin{array}{l}0.177 * * \\
(0.073)\end{array}$ \\
\hline $\ln \left(y_{i}\right)$ & $\begin{array}{l}0.608 * * \\
(0.110)\end{array}$ & $\begin{array}{l}0.565 * * \\
(0.107) \\
\end{array}$ & $\begin{array}{l}0.552 * * \\
(0.114)\end{array}$ & $\begin{array}{l}0.581^{* *} \\
(0.107)\end{array}$ \\
\hline $\begin{array}{l}\mathrm{N} \\
\mathrm{R}^{2} \\
\end{array}$ & $\begin{array}{r}868 \\
0.15 \\
\end{array}$ & $\begin{array}{r}894 \\
0.15 \\
\end{array}$ & $\begin{array}{r}845 \\
0.14 \\
\end{array}$ & $\begin{array}{r}897 \\
0.15 \\
\end{array}$ \\
\hline \multicolumn{5}{|c|}{ ic_int ${ }_{i}:$ dummy variable (1:important) \& I(p_relinc $\left.c_{i}\right):$ two dummy variables } \\
\hline$i c_{-} i m p_{i}$ & $\begin{array}{l}-0.373 * * \\
(0.112)\end{array}$ & $\begin{array}{l}-0.282^{* *} \\
(0.100)\end{array}$ & $\begin{array}{l}-0.484 * * \\
(0.162)\end{array}$ & $\begin{array}{l}-0.323^{* *} \\
(0.100)\end{array}$ \\
\hline less_inc $c_{i}$ & $\begin{array}{l}-0.298^{*} \\
(0.133)\end{array}$ & $\begin{array}{l}-0.367^{* *} \\
(0.122)\end{array}$ & $\begin{array}{c}0.010 \\
(0.121)\end{array}$ & $\begin{array}{l}-0.374^{* *} \\
(0.125)\end{array}$ \\
\hline more_inc $c_{i}$ & $\begin{array}{c}0.066 \\
(0.147)\end{array}$ & $\begin{array}{c}0.088 \\
(0.150)\end{array}$ & $\begin{array}{c}0.283^{*} \\
(0.129)\end{array}$ & $\begin{array}{l}-0.019 \\
(0.148)\end{array}$ \\
\hline $\ln \left(y_{i}\right)$ & $\begin{array}{l}0.608 * * \\
(0.109)\end{array}$ & $\begin{array}{l}0.573 * * \\
(0.107)\end{array}$ & $\begin{array}{l}0.566^{* *} \\
(0.113)\end{array}$ & $\begin{array}{l}0.588 * * \\
(0.106)\end{array}$ \\
\hline $\mathrm{N}$ & 868 & 894 & 845 & 897 \\
\hline $\mathrm{R}^{2}$ & 0.15 & 0.15 & 0.15 & 0.15 \\
\hline
\end{tabular}

Source: SOEP pretest modules 2008-2010. OLS-estimates. The dependent variable is respondents' life satisfaction. Additional controls include age, age squared and dummy variables for gender, education, firm size, public sector, marital status, children, white collar status, part-time, selfemployment and pretest sample affiliation. Robust standard errors in parentheses.

Significance levels: ** $(0.01), *(0.05),+(0.1)$.

Table 2 reveals a significantly negative association between income comparison intensity and happiness across all reference groups, irrespective of whether the intensity is represented by the ordinal measure or a dummy variable. Accordingly, those individuals who compare their income more intensively with the income of members of a reference group are less happy with their lives c. p. In particular, respondents who classify income comparisons as important exhibit a level of life satisfaction that is lower by $0.3-0.5$ on the $0-10$ satisfaction scale. $^{7}$

\footnotetext{
${ }^{7}$ Clark/Senik (2010) find a negative correlation between happiness and a general measure of income comparison intensity and Clark et al. (2013) report a likewise correlation between financial satisfaction and such general indicator of comparison intensity. These measures are, hence, not related to specific reference groups.
} 
Furthermore, using the ordinal measure of perceived relative income, we observe a significantly positive correlation between higher perceived relative income and subjective well-being. Comparison effects are asymmetric in Germany, as the findings for the dummy variable specification in the lower half of Table 2 reveal. Respondents who perceive to earn less than their job-related reference groups $\left(\operatorname{less}_{-} i n c_{i}\right.$ ) are significantly less happy, while employees who perceive to earn more $\left(\right.$ more_inc $\left.c_{i}\right)$ are not more satisfied with life. Evidently, job-related income comparisons in Germany are mostly upwards, which is in line with results for hypothetical reference groups based on age, gender, region, and education (Ferrer-i-Carbonell 2005). The effect on subjective well-being of perceiving to earn less than a job-related reference group instead of earning about the same is rather large: it is roughly equivalent to a one-standard-deviation loss of (log) net household income. This result highlights that perceptions of relative income might be more important for subjective wellbeing than actual incomes. Interestingly, we observe opposite asymmetric income comparison effects with respect to friends: only respondents who perceive to earn more than their friends exhibit significantly higher happiness levels. These diverging results relating to perceived relative income indicate that it is important to consider different predetermined reference groups in empirical work.

While we have, thus far, included the indicators of comparison intensity and perceived relative income separately in the empirical specifications, one might hypothesise that the relationship between relative income and satisfaction varies with the intensity of individual income comparison. Therefore, we have included interaction terms of, on the one hand, $i c_{-} i n t_{i}$ and $I\left(p_{-} r e l i n c_{i}\right)$ and, on the other hand, of $i c_{-} i m p_{i}$ and $l e s s_{-} i n c_{i}$ and more_inc $c_{i}$ in extended versions of our subjective well-being-specification (1). However, these interaction terms are never significantly different from zero (results are not documented). Hence, in our data it is the intensity of comparison per se which is related to life satisfaction, and not the combination of comparison intensity and income perceptions. ${ }^{8}$

\section{Robustness Checks}

The findings presented in Table 2 constitute convincing evidence that life satisfaction is negatively related to the intensity with which people compare their income to that of

\footnotetext{
${ }^{8}$ Clark et al. (2013) report that reference income and the intensity of income comparisons are negatively correlated with satisfaction with own income in the absence of an interaction term of these covariates in their empirical specification. If, however, the corresponding main effects and the interaction term are included jointly, the estimated parameter for this interaction term is significantly negative, while the estimated parameters of the main effects become insignificant.
} 
colleagues, people in the same occupation and friends. Moreover, perceived relative income is related positively to subjective well-being. However, there are a number of issues in the analysis of subjective well-being which we have ignored thus far and which may influence our findings. Subsequently, we present extensions of the basic empirical approach pursued in Section 3. They indicate the robustness of our results.

Table 3: Robustness Checks I: Specification Issues

\begin{tabular}{|c|c|c|c|c|}
\hline Reference Group & $\begin{array}{l}\text { Colleagues at } \\
\text { the work place }\end{array}$ & $\begin{array}{l}\text { Other people in } \\
\text { your } \\
\text { occupation }\end{array}$ & Your friends & $\begin{array}{l}\text { Most impor- } \\
\text { tant one w.r.t. } \\
\text { ic_int } t_{i}\end{array}$ \\
\hline \multicolumn{5}{|c|}{ logit-type Bernoulli QML-rating scale model (average marginal effects) } \\
\hline \multicolumn{5}{|c|}{ ic_int $_{i}:$ dummy variable (1:important) \& I(p_relinc $\left.c_{i}\right):$ two dummy variables } \\
\hline \multirow{2}{*}{$i c_{-} i m p_{i}$} & $-0.376^{* *}$ & $-0.277^{* *}$ & $-0.457 * *$ & $-0.318 * *$ \\
\hline & $(0.108)$ & $(0.097)$ & $(0.146)$ & $(0.100)$ \\
\hline \multirow{2}{*}{ less_inc $c_{i}$} & $-0.284^{*}$ & $-0.351^{* *}$ & 0.015 & $-0.359 * *$ \\
\hline & $(0.124)$ & $(0.114)$ & $(0.116)$ & $(0.120)$ \\
\hline \multirow{2}{*}{ more_inc $c_{i}$} & 0.068 & 0.100 & $0.293^{*}$ & -0.020 \\
\hline & $(0.154)$ & $(0.158)$ & $(0.133)$ & $(0.152)$ \\
\hline \multirow{2}{*}{$\ln \left(y_{i}\right)$} & $0.595 * *$ & $0.556 * *$ & $0.548 * *$ & $0.570 * *$ \\
\hline & $(0.104)$ & $(0.103)$ & $(0.108)$ & $(0.102)$ \\
\hline $\mathrm{N}$ & 868 & 894 & 845 & 897 \\
\hline \multicolumn{5}{|c|}{ observations with ic_int $_{i}>1$ only $(O L S)$} \\
\hline \multicolumn{5}{|c|}{ ic_int ${ }_{i}:$ dummy variable $(1$ :important $) \& I\left(p \_r e l i n c_{i}\right):$ two dummy variables } \\
\hline \multirow{2}{*}{$i c_{-} i m p_{i}$} & $-0.329 * *$ & $-0.212+$ & $-0.392 *$ & $-0.240 *$ \\
\hline & $(0.123)$ & $(0.108)$ & $(0.175)$ & $(0.108)$ \\
\hline \multirow{2}{*}{ less_inc $c_{i}$} & $-0.374^{*}$ & $-0.430 * *$ & -0.063 & $-0.417 * *$ \\
\hline & $(0.157)$ & $(0.134)$ & $(0.168)$ & $(0.137)$ \\
\hline \multirow{2}{*}{ more_inc $c_{i}$} & 0.066 & -0.031 & 0.099 & -0.147 \\
\hline & $(0.176)$ & $(0.162)$ & $(0.189)$ & $(0.154)$ \\
\hline \multirow{2}{*}{$\ln \left(y_{i}\right)$} & $0.642 * *$ & $0.611^{* *}$ & $0.545^{* *}$ & $0.581 * *$ \\
\hline & $(0.138)$ & $(0.118)$ & $(0.168)$ & $(0.114)$ \\
\hline $\mathrm{N}$ & 617 & 684 & 472 & 715 \\
\hline $\mathrm{R}^{2}$ & 0.15 & 0.17 & 0.16 & 0.16 \\
\hline $\begin{array}{ll}\text { ource: } & \text { SOEP pretest } \\
& \text { controls (not } \\
& \text { size, public se } \\
& \text { sample affilia }\end{array}$ & $\begin{array}{l}\text { odules 2008-2010. T } \\
\text { cumented) include a } \\
\text { tor, marital status, ch } \\
\text { on. Robust standard }\end{array}$ & $\begin{array}{l}\text { dependent variable is } \\
\text { age squared and dum } \\
\text { ren, white collar statu }\end{array}$ & $\begin{array}{l}\text { respondents' life s } \\
\text { my variables for g } \\
\text {, part-time, self-en }\end{array}$ & $\begin{array}{l}\text { faction. Additional } \\
\text { r, education, firm } \\
\text { yment and pretest } \\
01), *(0.05),+(0.1\end{array}$ \\
\hline
\end{tabular}

First, the OLS-specifications used thus far have two well-known shortcomings: they impose constant marginal effects and might lead to predictions outside the logically possible range of values. The second limitation is not relevant in our empirical study, since we do not observe predictions outside the zero-ten range of possible values in our OLS-specifications. However, constant marginal effects might represent a serious flaw. Therefore, we employ a rating scale model, recently suggested by Studer/Winkelmann (2012), which allows for varying marginal 
effects. Indeed, we find that the marginal effects slightly increase in comparison intensity in absolute values. However, the pairwise differences of these marginal effects are not significantly different from zero (for both cases the results of these tests are not documented). Moreover, the upper part of Table 3 reveals that our main results are unchanged when we use a rating scale model, i.e. the estimated average marginal effects of the parametric rating scale model are very similar to the OLS estimates. ${ }^{9}$

As a second check of robustness, we used a subsample including only those respondents who state that income comparisons are not completely unimportant $\left(i c_{-} i n t_{i}>1\right)$. The idea is to check whether our results are driven by group-specific heterogeneity, i.e. whether our estimated parameters pick up differences in the effect of relative income on subjective wellbeing between people who care about social comparison and people who do not. The lower part of Table 3 shows that the estimated parameters of $i c_{-} i n t_{i}$ are similar to the previous estimates. Moreover, asymmetric income comparison effects are observed for job-related reference groups again. However, for this subsample we do not find a relationship between relative income and subjective well-being for the reference group friends anymore. ${ }^{10}$

Recent research demonstrates that the U-shaped relationship between happiness and age is only prevalent when (pooled) cross-sections are used (Frijters/Beatton 2012, Kassenboehmer/ Haisken-deNew 2012). Since we employ such pooled cross-sectional data, it could be claimed that the relationship between life satisfaction and relative income varies with age. This idea has recently been put forward by FitzRoy et al. (2011). Using cross-sectional data for Germany (SOEP) inter alia, they find positive effects of comparison income based on hypothetical reference groups for respondents from the western part of the country who are 45 years of age or younger and negative effects for respondents over 45 years of age. To check whether we obtain similar results when using the measure of perceived relative income provided in the SOEP pretests, we also split our sample by age and reran our OLSspecifications for these subgroups. Table 4 below reveals that our main results do not change.

\footnotetext{
${ }^{9}$ This also holds if we use ordered-probit instead of OLS specifications as it is often done in applied work on subjective well-being (e.g. Ferrer-i-Carbonell 2005). However, ordered-probit specifications exhibit the disadvantage that they provide no simple measure of average marginal effects.

${ }^{10}$ We also estimated similar specifications based on a subsample with respondents only who state that income comparisons are completely unimportant $\left(i c_{-} i n t_{i}=1\right)$. Reassuringly, we do not find any evidence for a relationship between perceived relative income and the job-related reference groups "colleagues" and "people in your occupation". However, we observe a significant positive correlation between perceiving to earn more and life satisfaction with respect to the reference group "your friends" for those individuals who claim that income comparisons with respect to friends are completely unimportant. Hence, 50\% of our sample state (see Table 1) that comparing their own income with that of friends is completely unimportant to them, but nevertheless it makes the same respondents more satisfied if they earn more than their friends.
} 
We obtain significantly negative correlations between perceiving to earn less than the reference group and life satisfaction for both age groups in three out of four cases. Hence, using measures of perceived relative income we find no support for age-specific relationships between relative income and happiness. ${ }^{11}$ Note, however, that the estimated parameters are slightly greater in absolute values and the negative correlation between subjective well-being and the intensity of income comparisons is somewhat stronger for the older age group.

Table 4: Robustness Checks II: Age-specific Effects

\begin{tabular}{|c|c|c|c|c|}
\hline $\begin{array}{l}\text { Reference } \\
\text { Group }\end{array}$ & $\begin{array}{l}\text { Colleagues at } \\
\text { the work place }\end{array}$ & $\begin{array}{l}\text { Other people } \\
\text { in your } \\
\text { occupation }\end{array}$ & Your friends & $\begin{array}{l}\text { Most impor- } \\
\text { tant one w.r.t. } \\
\text { ic_int }_{i}\end{array}$ \\
\hline \multicolumn{5}{|c|}{ Sample with age $\leq 45$} \\
\hline$i c_{-} i m p_{i}$ & $\begin{array}{l}-0.317^{*} \\
(0.137)\end{array}$ & $\begin{array}{l}-0.180 \\
(0.128)\end{array}$ & $\begin{array}{l}-0.243 \\
(0.191)\end{array}$ & $\begin{array}{l}-0.229+ \\
(0.129)\end{array}$ \\
\hline$l e s s_{-} i n c_{i}$ & $\begin{array}{l}-0.269+ \\
(0.158)\end{array}$ & $\begin{array}{l}-0.285+ \\
(0.157)\end{array}$ & $\begin{array}{c}0.016 \\
(0.161)\end{array}$ & $\begin{array}{l}-0.407^{*} \\
(0.161)\end{array}$ \\
\hline more_inc $c_{i}$ & $\begin{array}{c}0.171 \\
(0.215)\end{array}$ & $\begin{array}{c}0.138 \\
(0.215)\end{array}$ & $\begin{array}{c}0.209 \\
(0.179)\end{array}$ & $\begin{array}{c}0.019 \\
(0.216)\end{array}$ \\
\hline $\ln \left(y_{i}\right)$ & $\begin{array}{l}0.572 * * \\
(0.136)\end{array}$ & $\begin{array}{l}0.589 * * \\
(0.138)\end{array}$ & $\begin{array}{l}0.614^{* *} \\
(0.146)\end{array}$ & $\begin{array}{l}0.574^{* *} \\
(0.135)\end{array}$ \\
\hline $\mathrm{N}$ & 507 & 519 & 498 & 520 \\
\hline $\mathrm{R}^{2}$ & 0.14 & 0.13 & 0.13 & 0.13 \\
\hline \multicolumn{5}{|c|}{ Sample with age $>45$} \\
\hline$i c_{-} i m p_{i}$ & $\begin{array}{l}-0.418 * \\
(0.192)\end{array}$ & $\begin{array}{l}-0.343^{*} \\
(0.162)\end{array}$ & $\begin{array}{l}-0.915^{* *} \\
(0.281)\end{array}$ & $\begin{array}{l}-0.410^{* *} \\
(0.156)\end{array}$ \\
\hline less_inc $c_{i}$ & $\begin{array}{l}-0.461+ \\
(0.246)\end{array}$ & $\begin{array}{l}-0.510^{*} \\
(0.203)\end{array}$ & $\begin{array}{l}-0.059 \\
(0.175)\end{array}$ & $\begin{array}{l}-0.343+ \\
(0.207)\end{array}$ \\
\hline more_inc $c_{i}$ & $\begin{array}{l}-0.010 \\
(0.203)\end{array}$ & $\begin{array}{l}-0.016 \\
(0.219)\end{array}$ & $\begin{array}{l}0.578 * * \\
(0.192)\end{array}$ & $\begin{array}{l}-0.045 \\
(0.205)\end{array}$ \\
\hline $\ln \left(y_{i}\right)$ & $\begin{array}{l}0.721 * * \\
(0.171)\end{array}$ & $\begin{array}{l}0.634 * * \\
(0.166)\end{array}$ & $\begin{array}{l}0.528 * * \\
(0.164)\end{array}$ & $\begin{array}{l}0.700 * * \\
(0.167)\end{array}$ \\
\hline $\mathrm{N}$ & 361 & 375 & 347 & 377 \\
\hline $\mathrm{R}^{2}$ & 0.20 & 0.20 & 0.23 & 0.19 \\
\hline \multicolumn{5}{|c|}{$\begin{array}{l}\text { Source: SOEP pretest modules 2008-2010. OLS-estimates. The dependent variable is respondents' } \\
\text { life satisfaction. Additional controls (not documented) include age, age squared and } \\
\text { dummy variables for gender, education, firm size, public sector, marital status, children, } \\
\text { white collar status, part-time, self-employment and pretest sample affiliation. Robust } \\
\text { standard errors in parentheses. } \\
\text { Significance levels: }{ }^{* *}(0.01),{ }^{*}(0.05),+(0.1) \text {. }\end{array}$} \\
\hline
\end{tabular}

Unfortunately, our pooled cross-sectional data does not allow us to control for unobserved individual heterogeneity directly, e.g. individual fixed effects. However, individual personality traits are considered as one important element of unobserved individual

\footnotetext{
${ }^{11}$ This result also holds when we focus on a sample of prime-age respondents (25-55 years of age) since the results for this age group are basically the same as for the entire sample of respondents (aged 17 to 65 years).
} 
heterogeneity, which might affect the relationship between income comparisons and happiness (e.g. Budria/Ferrer-i-Carbonell 2012, Boyce/Wood 2011). The SOEP pretest modules for the years 2008-2010 provide information on individual personality traits by means of the Big Five Inventory (BFI). The BFI model suggests that there are five dimensions to personality, i.e. an individual's openness-to-experience (O), conscientiousness (C), extroversion (E), agreeableness (A) and neuroticism (N). In a further check of robustness we, therefore, control for unobserved individual heterogeneity indirectly and include standardised personality scores for these five dimensions of the BFI as well as interactions of these scores with perceived relative income (less_inc $c_{i}$, more_inc $c_{i}$ ) into our empirical specifications. Table 5 presents the results. 
Table 5: Robustness Checks III: Personality Traits

\begin{tabular}{|c|c|c|c|c|}
\hline Reference Group & $\begin{array}{l}\text { Colleagues at } \\
\text { the work } \\
\text { place }\end{array}$ & $\begin{array}{l}\text { Other people } \\
\text { in your } \\
\text { occupation }\end{array}$ & Your friends & $\begin{array}{l}\text { Most important } \\
\text { one w.r.t. } \\
\text { ic_int } \text { ic }_{i}\end{array}$ \\
\hline \multicolumn{5}{|c|}{ ic_int $_{i}:$ dummy variable (1:important) \& I(p_relinc $\left.c_{i}\right):$ two dummy variables } \\
\hline$i c_{-} i m p_{i}$ & $\begin{array}{l}-0.355^{* *} \\
(0.110)\end{array}$ & $\begin{array}{l}-0.257 * * \\
(0.098)\end{array}$ & $\begin{array}{l}-0.396^{*} \\
(0.155)\end{array}$ & $\begin{array}{l}-0.287 * * \\
(0.098)\end{array}$ \\
\hline less_inc $_{i}$ & $\begin{array}{l}-0.289 * \\
(0.129)\end{array}$ & $\begin{array}{l}-0.276^{*} \\
(0.118)\end{array}$ & $\begin{array}{l}-0.008 \\
(0.119)\end{array}$ & $\begin{array}{l}-0.301^{*} \\
(0.119)\end{array}$ \\
\hline more_-inc $c_{i}$ & $\begin{array}{c}0.054 \\
(0.145)\end{array}$ & $\begin{array}{c}0.037 \\
(0.141)\end{array}$ & $\begin{array}{c}0.188 \\
(0.130)\end{array}$ & $\begin{array}{l}-0.018 \\
(0.145)\end{array}$ \\
\hline $\ln \left(y_{i}\right)$ & $\begin{array}{l}0.578^{* *} \\
(0.105)\end{array}$ & $\begin{array}{l}0.555^{* *} \\
(0.104)\end{array}$ & $\begin{array}{l}0.545^{* *} \\
(0.112)\end{array}$ & $\begin{array}{l}0.571^{* *} \\
(0.105)\end{array}$ \\
\hline Openness (O) & $\begin{array}{c}0.084 \\
(0.067)\end{array}$ & $\begin{array}{c}0.085 \\
(0.068)\end{array}$ & $\begin{array}{c}0.139 \\
(0.095)\end{array}$ & $\begin{array}{c}0.079 \\
(0.065)\end{array}$ \\
\hline Conscientiousness (C) & $\begin{array}{c}0.116+ \\
(0.061)\end{array}$ & $\begin{array}{l}0.185^{* *} \\
(0.058)\end{array}$ & $\begin{array}{c}0.157^{*} \\
(0.072)\end{array}$ & $\begin{array}{l}0.192 * * \\
(0.056)\end{array}$ \\
\hline Extroversion (E) & $\begin{array}{l}0.212 * * \\
(0.071)\end{array}$ & $\begin{array}{l}0.195 * * \\
(0.068)\end{array}$ & $\begin{array}{c}0.218^{*} \\
(0.095)\end{array}$ & $\begin{array}{l}0.201 * * \\
(0.067)\end{array}$ \\
\hline Agreeableness (A) & $\begin{array}{c}0.131 \\
(0.080)\end{array}$ & $\begin{array}{c}0.067 \\
(0.081)\end{array}$ & $\begin{array}{c}0.130 \\
(0.101)\end{array}$ & $\begin{array}{c}0.049 \\
(0.079)\end{array}$ \\
\hline Neuroticism (N) & $\begin{array}{l}-0.283^{* *} \\
(0.061)\end{array}$ & $\begin{array}{l}-0.242^{* *} \\
(0.064)\end{array}$ & $\begin{array}{l}-0.346^{* *} \\
(0.078)\end{array}$ & $\begin{array}{l}-0.288 * * \\
(0.061)\end{array}$ \\
\hline IA: less_inc $_{i} * \mathrm{O}$ & $\begin{array}{c}0.232 \\
(0.148)\end{array}$ & $\begin{array}{c}0.040 \\
(0.143)\end{array}$ & $\begin{array}{c}0.054 \\
(0.136)\end{array}$ & $\begin{array}{c}0.106 \\
(0.158)\end{array}$ \\
\hline IA: $l e s s_{-} i n c_{i} * \mathrm{C}$ & $\begin{array}{c}0.012 \\
(0.122)\end{array}$ & $\begin{array}{l}-0.127 \\
(0.126)\end{array}$ & $\begin{array}{l}-0.080 \\
(0.112)\end{array}$ & $\begin{array}{l}-0.149 \\
(0.129)\end{array}$ \\
\hline IA: $l e s s_{-} i n c_{i} * \mathrm{E}$ & $\begin{array}{l}-0.120 \\
(0.136)\end{array}$ & $\begin{array}{l}-0.044 \\
(0.133)\end{array}$ & $\begin{array}{c}0.020 \\
(0.137)\end{array}$ & $\begin{array}{l}-0.002 \\
(0.146)\end{array}$ \\
\hline IA: $\operatorname{less}_{-} i n c_{i} * \mathrm{~A}$ & $\begin{array}{l}-0.252+ \\
(0.148)\end{array}$ & $\begin{array}{c}0.033 \\
(0.146)\end{array}$ & $\begin{array}{l}-0.163 \\
(0.149)\end{array}$ & $\begin{array}{l}0.048 \\
(0.154)\end{array}$ \\
\hline IA: less_inc $_{i} * \mathrm{~N}$ & $\begin{array}{l}-0.040 \\
(0.139)\end{array}$ & $\begin{array}{l}-0.190 \\
(0.132)\end{array}$ & $\begin{array}{c}0.196+ \\
(0.114)\end{array}$ & $\begin{array}{c}0.032 \\
(0.134)\end{array}$ \\
\hline IA: $m o r e \_i n c_{i}{ }^{*} \mathrm{O}$ & $\begin{array}{l}-0.236+ \\
(0.133)\end{array}$ & $\begin{array}{l}-0.047 \\
(0.156)\end{array}$ & $\begin{array}{l}-0.248+ \\
(0.139)\end{array}$ & $\begin{array}{l}-0.182 \\
(0.149)\end{array}$ \\
\hline IA: $m o r e \_i n c_{i}^{*} \mathrm{C}$ & $\begin{array}{c}0.212 \\
(0.134)\end{array}$ & $\begin{array}{c}0.117 \\
(0.131)\end{array}$ & $\begin{array}{l}-0.074 \\
(0.121)\end{array}$ & $\begin{array}{l}0.050 \\
(0.129)\end{array}$ \\
\hline IA: $m o r e \_i n c_{i}{ }^{*} \mathrm{E}$ & $\begin{array}{c}0.030 \\
(0.148)\end{array}$ & $\begin{array}{l}-0.001 \\
(0.173)\end{array}$ & $\begin{array}{l}-0.178 \\
(0.136)\end{array}$ & $\begin{array}{c}0.064 \\
(0.168)\end{array}$ \\
\hline IA: $m o r e \_i n c_{i}{ }^{*} \mathrm{~A}$ & $\begin{array}{l}-0.012 \\
(0.145)\end{array}$ & $\begin{array}{c}0.095 \\
(0.144)\end{array}$ & $\begin{array}{c}0.173 \\
(0.149)\end{array}$ & $\begin{array}{c}0.178 \\
(0.151)\end{array}$ \\
\hline IA: more_inc ${ }_{i}^{*} \mathrm{~N}$ & $\begin{array}{c}0.232+ \\
(0.139)\end{array}$ & $\begin{array}{c}0.052 \\
(0.149)\end{array}$ & $\begin{array}{c}0.118 \\
(0.159)\end{array}$ & $\begin{array}{c}0.112 \\
(0.144)\end{array}$ \\
\hline $\mathrm{N}$ & 855 & 881 & 833 & 883 \\
\hline $\mathrm{R}^{2}$ & 0.24 & 0.23 & 0.23 & 0.23 \\
\hline
\end{tabular}

Source: SOEP pretest modules 2008-2010. OLS-estimates. The dependent variable is respondents' life satisfaction. Additional controls (not documented) include age, age squared and dummy variables for gender, education, firm size, public sector, marital status, children, white collar status, part-time, self-employment and pretest sample affiliation. Robust standard errors in parentheses. Significance levels: ** $(0.01), *(0.05),+(0.1)$. 
The estimated parameters across all specifications indicate that our main results remain stable. Once again we find negative correlations between income comparison intensity and subjective well-being for co-workers, people in the same occupation and friends. Moreover, for job-related reference groups income comparisons are mostly upwards and perceiving to earn less than the reference group has a negative association with life satisfaction. Note, furthermore, that we find significantly positive correlations between conscientiousness respectively extroversion and subjective well-being, while we observe negative correlations between neuroticism and subjective well-being (see also Boyce/Wood 2011). The estimated parameters of the interactions (IA) of the personality scores and perceived relative income are only weakly significant in some cases. Using the BFI to proxy for unobserved time-invariant heterogeneity we, accordingly, find no evidence that such individual heterogeneity affects the relationship between subjective well-being on the one hand, and perceived relative income and the intensity of income comparisons on the other hand. However, a comparison of the $\mathrm{R}^{2}$ of the specifications presented in the lower half of Table 2 and in Table 5 indicates that personality traits may be important additional correlates of subjective well-being.

\section{Summary}

This paper demonstrates the distinct importance of income comparison intensity and perceived relative income for subjective well-being with regard to job-related reference groups and friends. By the same token, the perceived income of other potential reference groups, such as neighbours, and parents when they were at the respondent's age, do not seem to affect subjective well-being. With respect to colleagues and people in the same occupation we find that (a) income comparison intensity and subjective well-being are negatively correlated, (b) income comparisons are mostly upwards and (c) perceiving to earn less than the reference group is negatively correlated with life satisfaction. These basic findings are robust with respect to alternative empirical specifications, age-specific differentiations and the impact of personality traits. Finally, our results underline the need for more data with detailed information on workers' perceptions of relative income. 


\section{References}

Boyce, Christopher J. and Alex M. Wood (2011), Personality and the Marginal Utility of Income: Personality Interacts with Increases in Household Income to Determine Life Satisfaction, Journal of Economic Behavior \& Organization 78(1-2), 183-191.

Budria, Santi and Ada Ferrer-i-Carbonell (2012), Income Comparisons and Non-Cognitive Skills, IZA DP No. 6419.

Clark, Andrew E., Frijters, Paul and Michael A. Shields (2008), Relative Income, Happiness, and Utility: An Explanation for the Easterlin Paradox and Other Puzzles, Journal of Economic Literature 46(1), 95-144.

Clark, Andrew E. and Claudia Senik (2010), Who Compares To Whom? The Anatomy of Income Comparisons in Europe, The Economic Journal 120(544), 573-594

Clark, Andrew E., Senik Claudia and Katsunori Yamada (2013), The Joneses in Japan: Income Comparisons and Financial Satisfaction, (http://www.parisschoolofeconomics.com/clark-andrew/CSYFeb2013Final.pdf, accessed March 5, 2013).

de la Garza, Adrian, Mastrobuoni, Giovanni, Sannabe, Atsushi and Katsunori Yamada (2012), The Relative Utility Hypothesis with and without Self-reported Reference Wages, (http://www.iser.osaka-u.ac.jp/coe/dp/pdf/no.164_dp_revised.pdf, accessed September 26, 2012).

Dolan, Paul, Peasgood, Tessa and Mathew White (2008), Do we Really Know What Makes us Happy? A Review of the Economic Literature on the Factors Associated with Subjective Well-being, Journal of Economic Psychology 29(1), 94-122.

Ferrer-i-Carbonell, Ada (2005), Income and Well-being: An Empirical Analysis of the Comparison Income Effect, Journal of Public Economics 89(5-6), 997-1019.

FitzRoy, Felix, Nolan, Michael N., Steinhardt, Max. F. and David Ulph (2011), So Far so Good: Age, Happiness, and Relative Income, SOEP papers No. 415.

Frijters, Paul and Tony Beatton (2012), The Mystery of the U-shaped Relationship Between Happiness and Age, Journal of Economic Behavior \& Organization 82(2-3), 525-542.

Guven, Cahit and Bent E. Sørensen (2012), Subjective Well-Being: Keeping up with the Perception of the Joneses, Social Indicators Research 109(3), 439-469.

Kassenboehmer, Sonja and John Haisken-DeNew (2012), Heresy or Enlightenment? The Well-being Age U-shape Effect is Flat, Economics Letters 117(1), 235-238.

Knight, John, Song, Lina and Ramani Gunatilaka (2009), Subjective Well-being and its Determinants in Rural China, China Economic Review 20(4), 635-649.

Knies, Gundi (2012), Income Comparisons Among Neighbours and Satisfaction in East and West Germany, Social Indicators Research 106(3), 471-489.

Layard, Richard, Mayraz, Guy and Stephen Nickell (2010), Does Relative Income Matter? Are the Critics Right?, 139-165, in: Diener, Ed, Helliwell, John F. and Daniel Kahneman (eds), International Differences in Well-Being, Oxford: Oxford University Press.

Luttmer, Erzo F.P. (2005), Neighbors as Negatives: Relative Earnings and Well-Being, Quarterly Journal of Economics 120(3), 963-1002.

McBride, Michael (2001), Relative-income Effects on Subjective Well-being in the Crosssection, Journal of Economic Behavior \& Organization 45(3), 251-278. 
Mayraz, Guy, Wagner, Gert G. and Jürgen Schupp (2010), Life Satisfaction and Relative Income: Perceptions and Evidence, (http://www.mayraz.com/papers/MWS09\%20 Relative\%20Income.pdf, accessed November 6, 2012).

Schneider, Simone M. and Jürgen Schupp (2013), Individual Differences in Social Comparison and its Consequences for Life Satisfaction: Introducing a Short Scale of the Iowa-Netherlands Comparison Orientation Measure. Social Indicators Research online first.

Schneider, Simone and Jürgen Schupp (2010), Measuring the Selection of Pay Referents - A Methodological Analysis of the Questions on Pay Referents in the 2008 and 2009 Pretest Modules. DIW-Data Documentation No. 48.

Senik, Claudia (2009), Direct Evidence on Income Comparisons and Their Welfare Effects, Journal of Economic Behavior \& Organization 72(1), 408-424.

Studer, Raphael and Rainer Winkelmann (2012), Econometric Analysis of Ratings - with an Application to Health Satisfaction, (http://www.econ.uzh.ch/faculty/studer/el.pdf, accessed November 6, 2012).

Wagner, Gert G., Frick, Joachim R. and Jürgen Schupp (2007), The German Socio-Economic Panel Study (SOEP) - Scope, Evolution, and Enhancements, Schmollers Jahrbuch 127(1), 139-169. 


\section{Appendix}

Table A1a: Descriptive statistics of income comparison variables

\begin{tabular}{|l|c|c|c|}
\hline Variables & Mean & Std. Dev. & $\mathrm{N}$ \\
\hline \multicolumn{1}{|c|}{ ic_int $_{i}$} & & & \\
\hline Neighbours & 1.731 & 1.255 & 1186 \\
Friends & 2.223 & 1.542 & 1191 \\
Colleagues & 3.223 & 2.018 & 1173 \\
People in your occupation & 3.637 & 2.102 & 1191 \\
People of your age & 2.765 & 1.836 & 1193 \\
Parents...your age & 1.964 & 1.460 & 1172 \\
Partner & 2.580 & 1.884 & 1091 \\
Other male (in general) & 2.319 & 1.701 & 1176 \\
Other female (in general) & 2.432 & 1.760 & 1173 \\
\hline \multicolumn{1}{|c|}{ I(p_relinc $\left.{ }_{i}\right)$} & & & \\
\hline Neighbours & 2.707 & 1.109 & 810 \\
Friends & 2.829 & 0.899 & 994 \\
Colleagues & 2.853 & 0.772 & 1031 \\
People in your occupation & 2.813 & 0.737 & 1058 \\
People of your age & 2.844 & 0.914 & 932 \\
Parents...your age & 3.388 & 1.272 & 923 \\
Partner & 3.073 & 1.390 & 869 \\
Other male (in general) & 3.148 & 1.003 & 908 \\
Other female in general & 2.555 & 1.034 & 916 \\
\hline
\end{tabular}

Source: SOEP pretest modules 2008-2010. Weighted statistics.

Table A1b: Descriptive statistics of covariates

\begin{tabular}{|l|c|c|c|}
\hline Variables & Mean & Std. Dev. & $\mathrm{N}$ \\
\hline Net household income $(\mathrm{ln})$ & 7.684 & 0.586 & 975 \\
Male & 0.471 & 0.499 & 1211 \\
Age (in years) & 42.406 & 11.841 & 1211 \\
Apprenticeship & 0.651 & 0.477 & 1211 \\
University & 0.199 & 0.399 & 1211 \\
Part-time & 0.244 & 0.430 & 1211 \\
Firm size: $5 \leq \mathrm{x}<20$ employees & 0.192 & 0.394 & 1211 \\
Firm size: $20 \leq \mathrm{x}<200$ empl. & 0.292 & 0.455 & 1211 \\
Firm size: $200 \leq \mathrm{x}<2000$ empl. & 0.150 & 0.358 & 1211 \\
Firm size: $\geq 2000$ employees & 0.174 & 0.379 & 1211 \\
Public sector & 0.239 & 0.427 & 1211 \\
Married & 0.577 & 0.494 & 1211 \\
Children in the household & 0.321 & 0.467 & 1211 \\
White collar worker & 0.570 & 0.495 & 1211 \\
Self-employed & 0.104 & 0.305 & 1211 \\
Pretest09 & 0.348 & 0.476 & 1211 \\
Pretest10 & 0.279 & 0.449 & 1211 \\
\hline
\end{tabular}

Source: SOEP pretest modules 2008-2010. Weighted statistics. 
Table A2: Complete results: Subjective Well-Being and Income Comparisons

\begin{tabular}{|c|c|c|c|c|}
\hline $\begin{array}{l}\text { Reference } \\
\text { Group }\end{array}$ & $\begin{array}{l}\text { Colleagues at } \\
\text { the work place }\end{array}$ & $\begin{array}{l}\text { Other people in your } \\
\text { occupation }\end{array}$ & Your friends & $\begin{array}{l}\text { Most important } \\
\text { one w.r.t. ic_int } t_{i}\end{array}$ \\
\hline \multicolumn{5}{|c|}{ ic_int $_{i}:$ ordinal $\& I\left(p \_r e l i n c_{i}\right):$ ordinal } \\
\hline$i c_{-} i n t_{i}$ & $\begin{array}{l}-0.083^{* *} \\
(0.028)\end{array}$ & $\begin{array}{l}-0.074 * * \\
(0.026) \\
\end{array}$ & $\begin{array}{l}-0.087^{*} \\
(0.034)\end{array}$ & $\begin{array}{l}-0.088^{* *} \\
(0.027)\end{array}$ \\
\hline$I\left(p_{-}\right.$relinc $\left.i\right)$ & $\begin{array}{c}0.133+ \\
(0.071) \\
\end{array}$ & $\begin{array}{l}0.229 * * \\
(0.071)\end{array}$ & $\begin{array}{c}0.106+ \\
(0.056) \\
\end{array}$ & $\begin{array}{l}0.177 * * \\
(0.073)\end{array}$ \\
\hline $\ln \left(y_{i}\right)$ & $\begin{array}{l}0.608 * * \\
(0.110)\end{array}$ & $\begin{array}{l}0.565^{* *} \\
(0.107)\end{array}$ & $\begin{array}{l}0.552 * * \\
(0.114)\end{array}$ & $\begin{array}{l}0.581^{* *} \\
(0.107)\end{array}$ \\
\hline Male & $\begin{array}{l}-0.127 \\
(0.117) \\
\end{array}$ & $\begin{array}{l}-0.174 \\
(0.114) \\
\end{array}$ & $\begin{array}{l}-0.115 \\
(0.117)\end{array}$ & $\begin{array}{l}-0.159 \\
(0.114)\end{array}$ \\
\hline Age (in years) & $\begin{array}{l}-0.077^{*} \\
(0.031) \\
\end{array}$ & $\begin{array}{l}-0.092 * * \\
(0.031) \\
\end{array}$ & $\begin{array}{l}-0.063 * \\
(0.032) \\
\end{array}$ & $\begin{array}{l}-0.094^{* *} \\
(0.031) \\
\end{array}$ \\
\hline Age squared & $\begin{array}{c}0.001+ \\
(0.000)\end{array}$ & $\begin{array}{c}0.001 * \\
(0.000)\end{array}$ & $\begin{array}{c}0.001 \\
(0.000)\end{array}$ & $\begin{array}{c}0.001^{*} \\
(0.000)\end{array}$ \\
\hline Apprent. & $\begin{array}{c}0.308+ \\
(0.184) \\
\end{array}$ & $\begin{array}{c}0.283 \\
(0.180) \\
\end{array}$ & $\begin{array}{c}0.309 \\
(0.188) \\
\end{array}$ & $\begin{array}{c}0.277 \\
(0.179) \\
\end{array}$ \\
\hline University & $\begin{array}{l}0.409^{*} \\
(0.201)\end{array}$ & $\begin{array}{c}0.375+ \\
(0.194)\end{array}$ & $\begin{array}{c}0.430 * \\
(0.204)\end{array}$ & $\begin{array}{c}0.390^{*} \\
(0.191) \\
\end{array}$ \\
\hline Part-time & $\begin{array}{l}-0.187 \\
(0.129)\end{array}$ & $\begin{array}{l}-0.305^{*} \\
(0.125)\end{array}$ & $\begin{array}{l}-0.178 \\
(0.131)\end{array}$ & $\begin{array}{l}-0.262^{*} \\
(0.125)\end{array}$ \\
\hline $\begin{array}{l}\text { Firm size: } 5 \leq \mathrm{x} \\
<20 \text { employees }\end{array}$ & $\begin{array}{c}0.243 \\
(0.218)\end{array}$ & $\begin{array}{c}0.109 \\
(0.208)\end{array}$ & $\begin{array}{c}0.118 \\
(0.206)\end{array}$ & $\begin{array}{c}0.124 \\
(0.211)\end{array}$ \\
\hline $\begin{array}{l}\text { Firm size: } 20< \\
x<200 \text { empl. }\end{array}$ & $\begin{array}{l}-0.124 \\
(0.216) \\
\end{array}$ & $\begin{array}{l}-0.199 \\
(0.207)\end{array}$ & $\begin{array}{l}-0.295 \\
(0.204) \\
\end{array}$ & $\begin{array}{l}-0.177 \\
(0.209) \\
\end{array}$ \\
\hline $\begin{array}{l}\text { Firm size: } 200< \\
x<2000 \text { empl. }\end{array}$ & $\begin{array}{c}0.134 \\
(0.217)\end{array}$ & $\begin{array}{c}0.080 \\
(0.209)\end{array}$ & $\begin{array}{c}0.015 \\
(0.213)\end{array}$ & $\begin{array}{c}0.083 \\
(0.211)\end{array}$ \\
\hline $\begin{array}{l}\text { Firm size: } \\
x \geq 2000 \text { empl. }\end{array}$ & $\begin{array}{c}0.057 \\
(0.225) \\
\end{array}$ & $\begin{array}{l}-0.064 \\
(0.219) \\
\end{array}$ & $\begin{array}{l}-0.133 \\
(0.221) \\
\end{array}$ & $\begin{array}{l}-0.040 \\
(0.221) \\
\end{array}$ \\
\hline Public sector & $\begin{array}{c}0.286^{*} \\
(0.112)\end{array}$ & $\begin{array}{l}0.306^{* *} \\
(0.111)\end{array}$ & $\begin{array}{c}0.281^{*} \\
(0.114)\end{array}$ & $\begin{array}{l}0.289 * * \\
(0.111)\end{array}$ \\
\hline Married & $\begin{array}{l}0.324^{*} \\
0.132) \\
\end{array}$ & $\begin{array}{c}0.271^{*} \\
(0.130)\end{array}$ & $\begin{array}{c}0.356^{*} \\
(0.139) \\
\end{array}$ & $\begin{array}{c}0.288^{*} \\
(0.130) \\
\end{array}$ \\
\hline $\begin{array}{l}\text { Children in the } \\
\text { household }\end{array}$ & $\begin{array}{l}-0.067 \\
(0.128)\end{array}$ & $\begin{array}{c}0.001 \\
(0.124)\end{array}$ & $\begin{array}{l}-0.112 \\
(0.130)\end{array}$ & $\begin{array}{l}-0.020 \\
(0.124)\end{array}$ \\
\hline $\begin{array}{l}\text { White collar } \\
\text { worker }\end{array}$ & $\begin{array}{l}0.329 * * \\
(0.120)\end{array}$ & $\begin{array}{l}0.378 * * \\
(0.119)\end{array}$ & $\begin{array}{c}0.294^{*} \\
(0.121) \\
\end{array}$ & $\begin{array}{l}0.353^{* *} \\
(0.119)\end{array}$ \\
\hline Self-employed & $\begin{array}{c}0.404 \\
(0.256) \\
\end{array}$ & $\begin{array}{c}0.395 \\
(0.248) \\
\end{array}$ & $\begin{array}{c}0.334 \\
(0.243) \\
\end{array}$ & $\begin{array}{c}0.340 \\
(0.245) \\
\end{array}$ \\
\hline Pretest09 & $\begin{array}{l}-0.111 \\
(0.122)\end{array}$ & $\begin{array}{l}-0.130 \\
(0.122)\end{array}$ & $\begin{array}{l}-0.107 \\
(0.126)\end{array}$ & $\begin{array}{l}-0.119 \\
(0.121)\end{array}$ \\
\hline Pretest10 & $\begin{array}{l}-0.021 \\
(0.121) \\
\end{array}$ & $\begin{array}{l}-0.040 \\
(0.120) \\
\end{array}$ & $\begin{array}{l}-0.024 \\
(0.125) \\
\end{array}$ & $\begin{array}{l}-0.043 \\
(0.119) \\
\end{array}$ \\
\hline $\begin{array}{l}\mathrm{N} \\
\mathrm{R}^{2}\end{array}$ & $\begin{array}{r}868 \\
0.15 \\
\end{array}$ & $\begin{array}{r}894 \\
0.15\end{array}$ & $\begin{array}{r}845 \\
0.14 \\
\end{array}$ & $\begin{array}{r}897 \\
0.15\end{array}$ \\
\hline
\end{tabular}

Source: SOEP pretest modules 2008-2010. For additional information see Table 2 in the main text. 